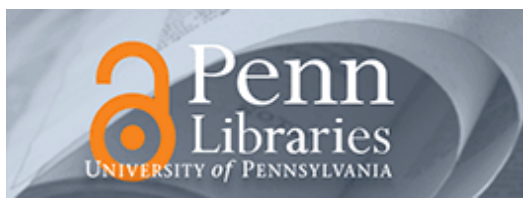

University of Pennsylvania ScholarlyCommons

Wharton Pension Research Council Working

Papers

Wharton Pension Research Council

$4-1-2010$

\title{
Rating Retirement Advice: A Critical Assessment of Retirement Planning Software
}

John A. Turner

Pension Policy Center, jaturner49@aol.com

Follow this and additional works at: https://repository.upenn.edu/prc_papers

Part of the Economics Commons

Turner, John A., "Rating Retirement Advice: A Critical Assessment of Retirement Planning Software" (2010). Wharton Pension Research Council Working Papers. 189.

https://repository.upenn.edu/prc_papers/189

This paper is posted at ScholarlyCommons. https://repository.upenn.edu/prc_papers/189

For more information, please contact repository@pobox.upenn.edu. 


\title{
Rating Retirement Advice: A Critical Assessment of Retirement Planning Software
}

\begin{abstract}
This paper develops a rating system for internet-based free retirement planning software that assumes unsophisticated users. The rating system takes into account two of the most important sources of retirement income - Social Security and investments — and the two main determinants of retirement income needs - the length of the planning period and the target replacement rate or target retirement income. We illustrate the rating approach with a sample of programs, and we find that these often tend to do a poor job in the way they handle Social Security benefits. Some encourage older persons to assume large benefit cuts, which we view as unlikely.

\section{Keywords}

Retirement, Security, Benefits, Planning, Program, Income, Target Rate, Expected Return, Software, Monte Carlo
\end{abstract}

\section{Disciplines}

Economics 


\title{
Rating Retirement Advice: A Critical Assessment of Retirement Planning Software
}

\author{
John A. Turner
}

April 2010

\author{
PRC WP2010-03 \\ Pension Research Council Working Paper \\ Pension Research Council \\ The Wharton School, University of Pennsylvania \\ 3620 Locust Walk, 3000 SH-DH \\ Philadelphia, PA 19104-6302
}

Tel: 215.898.7620 Fax: 215.573.3418

Email: prc@wharton.upenn.edu

http://www.pensionresearchcouncil.org

Opinions and conclusions are solely those of the author(s) and do not reflect views of the institutions supporting the research, with whom the authors are affiliated, or the Pension Research Council. Copyright 2010 (C) Pension Research Council of the Wharton School of the University of Pennsylvania. All rights reserved. 


\title{
Rating Retirement Advice: A Critical Assessment of Retirement Planning Software
}

\author{
John A. Turner
}

This paper develops a rating system for internet-based free retirement planning software that assumes unsophisticated users. The rating system takes into account two of the most important sources of retirement income-Social Security and investments-and the two main determinants of retirement income needs - the length of the planning period and the target replacement rate or target retirement income. We illustrate the rating approach with a sample of programs, and we find that these often tend to do a poor job in the way they handle Social Security benefits. Some encourage older persons to assume large benefit cuts, which we view as unlikely. 


\title{
Rating Retirement Advice: A Critical Assessment of On-line Retirement Planning Software
}

\author{
John A. Turner
}

The defined contribution-based U.S. retirement system places financial decision-making responsibilities on workers. As a consequence, household financial literacy has come under scrutiny, and studies reveal surprisingly low levels of financial knowledge among the American public (e.g., Lusardi and Mitchell 2009). Perhaps in response to the widespread lack of financial literacy, the Internet has evolved into a primary source of financial information for many households. Four out of five adults have Internet access at home, work, or some other location, versus fewer than one-quarter a decade ago (Investment Company Institute 2006). Workers are relying on the Internet to access a wide range of information affecting their financial lives and choices, and the use of the Internet is expected to increase in the future. On-line financial calculators are now available for calculating mortgages, student loans, 401(k) distributions, annuities, and retirement planning.

A recent study of a small sample of online retirement planning programs (Turner and Witte 2009) finds that many programs contain serious deficiencies. For example, they may contain misleading or incorrect information about Social Security. In addition, they permit use of rates of return that far exceed reasonable assumptions about the future. While that study reviewed a small number of programs, it did not develop a rating scheme nor provide ratings for specific programs. This paper fills the knowledge gap by developing a rating scale for retirement planning software and implementing it to illustrate how it can be used. The scale takes into account several key issues in retirement planning relating to both sources of income and income needs: 
- Social Security benefits and age at first receipt;

- Expected rates of return and risk on investments;

- Life expectancy and the length of the planning period; and

- Target replacement rates or target retirement incomes.

In what follows we first review previous studies related to retirement planning software.

Second, we selectively discuss studies providing evidence as to the lack of worker knowledge in key areas of retirement planning. Third, we develop a rating system for retirement planning software, taking into account lack of worker knowledge. Fourth, we show how to implement the rating approach and discuss some of the key problem areas including the treatment of Social Security. A final section concludes.

\section{Previous Studies}

Systematic academic investigation of financial planning software is still in its infancy. Warshawsky and Ameriks (2000) examine a single financial planning program, Quicken, and instead of running scenarios, they feed the program real-world data on individuals drawn from the Federal Reserve Board's Survey of Consumer Finances. The authors note that this software does not recognize many post-retirement uncertainties facing households, including life expectancy, and returns on financial and human capital assets. In Sondergeld et al. (2003), the authors evaluate a number of retirement planning programs and find that most do not recognize the major post-retirement risks - in fact, the programs often mask the risks since they tend to report a single outcome, without considering the range of possible outcomes that could result from different circumstances. For instance the programs overlook the impact of living longer than expected or the stock market performing worse than expected. 
Retirement planning software available at four major websites is analyzed by Bodie (2003), who concludes that the programs have a pro-equity, and thus pro-risk, bias. He also finds that the programs recommend the worker reduce equity holdings with age, while many financial theorists have argued for a constant equity fraction over the lifetime independent of time horizon. He also argues that the conventional focus on the probability of a financial shortfall is shortsighted, since it ignores the severity of a shortfall when it occurs.

Kotlikoff (2006) asks whether financial planning software can do a good job with what he sees as the right objective, namely consumption smoothing. He notes that traditional financial planning software often asks participants to choose a spending target in retirement, which he finds problematic for two reasons. First, people find it difficult to accurately determine a spending target. Thus one’s current consumption level may be a poor guide for a future spending target, if that level is unsustainably high or low. Second, even small errors in spending targets can lead to large errors in saving levels, because the accumulation period and the deaccumulation period are both lengthy. After reviewing the advice provided by four well-known financial services companies, Kotlikoff concludes that they all advise dramatic oversaving compared to what workers would need to maintain a constant level of consumption relative to pre-retirement. Not only does he challenge standard financial planning software, but he also argues against the conventional replacement rate methodology often used in standard financial planning approaches.

Twelve internet-based programs are examined in Dowd et al. (2008) who focus on the handling of medical care expenditures in detail. That study finds that most programs do not consider medical care expenditures as a separate category of expenditures, and hence users of such programs would likely underestimate their risk exposure to such costs in retirement. A 
paper by Madden (2008) evaluates five retirement planning programs. The author indicates wide variability in the programs' quality, and a large dispersion in calculated saving shortfalls across study, in part because three of the five do not include Social Security benefits in their calculations.

Most recently, Turner and Witte (2009) examine five free internet-based programs and seven fee-based programs. That study finds that the internet-based retirement planning software do a poor job in providing accurate information on future Social Security benefits as well as other Social Security information. For example, some programs set the rate of indexation of Social Security benefits in payment at less than the rate of inflation, which is contrary to system rules. Other programs allow the user to specify that they would start receiving Social Security benefits prior to the age of 62, which is generally not feasible. Still other programs allow users to grossly overestimate their Social Security benefits. The programs generally are more focused on investments, which for most workers are of secondary importance to Social Security.

While the surveys just described focus on the household as the end-user, several others take the perspective of professional financial planners (for example, McClure 2005; Landis 2007). In the popular press, some analysts have commented on the positive and negative aspects of retirement planning programs. Carnahan (2005) reviews a few programs that offer advice on investing in specific funds, an issue not considered here.

\section{Knowledge and Errors in Decision-Making}

In order to understand what planning software should do, it is helpful to review what individuals know regarding key issues in retirement planning and what mistakes they make. Social Security. Since virtually all retirees receive Social Security, and since this is the source of 
a major portion of many peoples' incomes, it is clearly important to evaluate what people know about this issue. The 2008 Metlife (2008) Retirement Income IQ Study reported that roughly 30 percent of pre-retirees overestimated average Social Security benefits. Mitchell (1988) and Gustman and Steinmeier (2003) documented that most individuals have a low level of knowledge about their future Social Security benefits. Rohwedder and Kleinjans (2004) found that, among people within two years of taking Social Security benefits, about 30 percent responded that they did not know what their Social Security benefits would be. Among those who indicated that they did know, about half were accurate to within 10 percent of their actual benefits but 25 percent overestimated their future benefits by 10 percent or more. Benitez-Silva et al. (2009) also found a low level of knowledge concerning Social Security’s rules for benefit receipt, and they suggested that lack of knowledge had an effect on retirement well-being.

Users of retirement planning software can obtain a good estimate of their future benefits either from their annual statement from the Social Security Administration or by going to the Social Security Administration's website, where they can calculate their future benefits based on their own earnings record. Both these calculations of Social Security benefits assume no future (real) wage growth or price inflation; that is, they assume that the most recent earnings on record, which generally would be one or two years old, would continue into the future. While for some older workers this might be accurate, for young workers, the assumption of no real earnings growth would be wrong as a rule.

Some people may retire early due to errors in decision making (Hill and Reno 2005). This mistake would cause them to claim Social Security benefits earlier than they otherwise would. They may overestimate the value of a lump sum benefit from a defined contribution plan in terms of its ability to provide a stream of income during retirement. They may underestimate the 
effect of inflation eroding the real value of fixed benefits, such as those often provided by defined benefit plans. They may underestimate their life expectancy and overestimate the expected return on their investments.

Rates of Return and Risk. Many people have a poor understanding and low level of knowledge about financial market issues (Lusardi and Mitchell 2008; 2009). Many studies have shown that individuals tend to overestimate future investment returns (Sondergeld and Greenwald 2005).

Length of the Planning Period. Survey data indicate that many people tend to underestimate their life expectancy. The Society of Actuaries (2004) reported that a majority of the male respondents (67 percent of pre-retirees) underestimated the life expectancy of the average 65year-old man. Of that group, 42 percent underestimated average life expectancy by 5 years or more. Roughly half (54 percent) of pre-retiree females underestimated the life expectancy of the average 65-year-old woman. The MetLife (2008) Retirement IQ Survey noted that 60 percent of respondents underestimated the probability that a person would live to age 85 , even after being told that 85 was the average life expectancy for people age 65 . The people in the survey were age 56-65 and within five years of their expected retirement. Interestingly however, Hurd and McGarry (1997) found that when people in the Health and Retirement Survey were asked their probability of surviving to a given age, the individual probabilities aggregated closely to life table probabilities. This issue is an unresolved area. Asking people whether they had high, medium, or low life expectancy might be a good way of approaching the issue, but that has not been investigated.

Target Replacement Rate or Target Retirement Income. In Metlife (2008) survey, almost half of pre-retirees (49 percent) underestimated how much money income they will need in retirement, believing that they will only need 50 percent or less of their pre-retirement income. 
Thus, when programs ask people to input their retirement income needs, they may tend to underestimate their needs. Scholz and Seshadri (2009) estimate that the median replacement rate to maintain pre-retirement consumption, when average lifetime income is in the denominator, is 68 percent. Furthermore, they point to large differences in the optimal replacement rate across different demographic groups. For example, the median optimal replacement rate for singles was 55 percent, while it was 75 percent for married couples. Households that are single with several children would have even lower optimal replacement rates than 55 percent.

\section{A Rating System}

Next we turn to developing a rating system for retirement planning software, taking into account the evidence that people need assistance in providing some of the key inputs. Our approach is designed to rate internet-based free retirement planning software and we assume an unsophisticated user. ${ }^{1}$ The basic approach is that heterogeneity in individual circumstances relating to some key issues in retirement planning should be recognized. Accordingly for key issues such as life expectancy, individuals should supply the inputs. At the same time, individuals need to have some help from the programs in determining reasonable values, and the programs should check to make sure that values provided are inside a reasonable range.

The rating system evaluates how well the programs handle four broad issues that affect preparedness for retirement: Social Security benefits and age at first receipt, the expected rates of return and risk on investments, life expectancy and the length of the planning period, and the target replacement rate or target retirement income. Social Security benefits and issues relating to financial market risk and rate of return cover two of the main areas of retirement income. The 
length of the planning period and the target replacement rate or target income determine the amount of resources needed.

The maximum score is 100 points. The points are divided evenly between the ratings for sources of retirement income and the ratings for determinants of the amount of retirement income needed. Because Social Security is considerably more important for most people than investments as a source of retirement income, Social Security receives a maximum of 30 points, while rates of return and investments risk can receive a maximum of 20 points. The length of the planning period and the target replacement rate or target retirement income both are allocated a maximum of 25 points. Each of the categories is then organized around the following three questions:

1) Does the software provide useful information as background and as assistance in choosing inputs?

2) Does the software reject obviously false inputs, and question possibly false inputs? This area includes rating on the extent of granularity in the feedback (the extent to which it takes into account information about the user).

3) What advice does the software provide following the calculations done by the program? Issues related to ease of use are considered as they affect the specific areas. Similarly, the handling of issues concerning spouses are considered as they affect the specific rating areas.

Social Security Benefits and Age at First Receipt. Couples have a number of different claiming strategies for when to take Social Security benefits, so our rating system checks to see whether the basic issues are covered adequately. The ratings focus on the following issues:

1. Understanding the importance of Social Security in retirement planning. Does the program have as the default that Social Security benefits are taken into account in projections? 
Some programs, rather than indicating the importance of Social Security, ask the user if he or she wants to include Social Security benefits in the calculation of retirement income.

\section{Accurate statements about the possible effects of the projected insufficiency of}

Social Security financing. If the program discusses the future financing of Social Security, does it provide accurate statements about the importance of Social Security benefits in the future? Some programs make statements about the financial solvency of the Social Security system that provide a misleading impression for people currently near retirement, who would be likely be unaffected by future changes in Social Security.

3. Benefit indexation. Does the program indicate that Social Security benefits are indexed for inflation? Some programs set the inflation rate at a higher level than the rate at which Social Security benefits are indexed.

4. Level of Social Security benefits. Does the program indicate the need to obtain an accurate estimate of future Social Security benefits because of the importance of those benefits to most workers? For example, does the program suggest the user check his or her annual statement from Social Security or go to the Social Security website to calculate his or her benefits?

5. Actuarial adjustment of postponed benefits. Does the program indicate that postponing receipt of benefits past age 62, up to age 70, would result in the user receiving higher annual benefits? Does the program adjust the value of Social Security benefits if the user runs an alternative scenario with a later retirement age? Some programs do not adjust benefits for postponed retirement.

6. Earnings test. Does the program notify the user that if the user takes Social Security benefits while still working, the benefits would be reduced if the worker earns above a certain amount between ages 62 and the normal retirement age? 
7. Treatment of spousal and survivor benefits. Does the program allow for spousal and survivor benefits? Does the program provide information on those benefits? Does the program allow for both spouses receiving their own benefits?

8. Benefit levels. Does the program reject obviously inaccurate estimates of Social Security benefits? Some programs have no constraint on levels of Social Security benefits inputted by the user. In 2009, average Social Security annual benefits were $\$ 13,300$ for a widow, $\$ 13,800$ for a retired worker, and \$22,500 for a retired couple, both of whom were receiving benefits. The maximum annual benefit a worker retiring at age 66 could receive in 2010 is \$28,200 (U.S. Social Security Administration 2010).

9. Granularity. Does the program recognize that benefit levels vary across users, and have different rejection levels for users at different likely wealth and income groupings? For example, a user who indicates low earnings would have a lower level of likely Social Security benefits than a user with high earnings.

10. Earliest eligibility age. Does the program indicate that the earliest age at which Social Security benefits can be received is 62 ? Does the program constrain Social Security benefits to be zero earlier ages? This is important since some programs allow the user to specify receipt of Social Security benefits at earlier ages. Studies indicate that some people do not know the correct age. While generally workers should claim benefits by age 70 because there are no actuarial increases when benefits are postponed past that age, presumably few workers make the error of claiming benefits at a later age.

11. Advice if wealth is insufficient. Does the program suggest postponing receipt of Social Security benefits if the user has saved insufficiently? Does the program automatically provide results for later retirement ages? Some programs only suggest saving more, even when that 
means saving more than the user's total income. The Social Security Administration's benefits calculator, which is available on-line, automatically provides benefit estimates for retirement at three different ages.

Investment Expected Returns and Risk. A common problem with many of the retirement planning programs examined by Turner and Witte (2009) is that the software uses or accepts rates of return that are too high. This error occurs for a number of reasons. First, market rates of return may exceed the rates of return individuals receive due to investment fees they pay. Second, historical rates of return may be a poor guide for future rates of return, which may be lower (Saving 2009). Third, individuals tend to under-perform the market because of errors they make in investing, such as selling (or not buying) when the market is low and buying when it is high. For these reasons, individual investors have earned more than 1 percent less than a broad market average for the New York Stock Exchange over long periods (Dichev 2007). Fourth, the rates of return used ignore whether the investments are in tax preferred or taxable accounts, often not taking into account taxes at all. Clearly it would be preferable for taxes to be treated separately from before-tax rates of return. Fifth, studies have shown that individuals tend to overestimate future investment returns (Sondergeld and Greenwald 2005). Sixth, deterministic programs do not adjust historical rates of return for risk. Seventh, stochastic programs often under-represent the risk of large stock market declines.

Taking into account those issues, the rating system checks for the following:

\section{Assistance in Choosing Inputs.}

1. Assistance provided. Does the program provide assistance in setting rates of return?

2. Investment fees. Do the rates of return used take into account fees charged on the accounts? Does the program indicate the importance of considering fees? 
3. Risk. Does the program take into account investment risk? If not does the exercise does it provide more than one possible outcome, as a way of demonstrating the effects of risk? If so, does it use Monte Carlo simulations to show a range of outcomes?

4. Treatment of taxed vs tax-preferenced assets. Does the program treat rates of return in taxable and tax-preferenced accounts differently?

5. Ease of use in running alternative scenarios. If the program does not use Monte Carlo simulation, does it facilitate running a range of different scenarios?

6. Age varying rates of return. Does the program allow the user to set different rates of return at different ages, allowing for a movement toward a more conservative portfolio?

7. Consistency of rate of return and inflation assumptions. Does the program link the rate of inflation to levels of rates of return?

$\underline{\text { Rejection of False or Inappropriate Inputs }}$

8. Rejection of inaccurate inputs on rates of return. Does the program reject rates of return of 10 percent or higher when it requests a single rate for a portfolio? Does the program question rates of return of 8 percent or higher for a single rate for a portfolio?

Advice Based on the Projection of Retirement Income.

9. Advice provided if savings are insufficient. Does the program provide advice as to adjusting investments if the person has saved insufficiently? Does this advice include investing in riskier portfolios, and if so does it explain about the greater risk? Does the advice take into account the tax consequences of selling assets in taxable accounts?

Life Expectancy vs the Length of the Planning Period. Individual differences in life expectancy are considerable. Studies have indicated differences of a decade or more across identifiable demographic and economic groups, for example low-income African American men 
compared to high-income Asian women (Murray et al. 2006). In addition, groups differ based on healthy behaviors, such as between nonsmokers and smokers and between nondrinkers and heavy drinkers.

People should plan for a longer period than their personal life expectancy because they have a chance of living longer. However, there is a tension between setting a long planning period to avoid the risk of living longer than expected, and setting a short planning period to avoid the risk of living a shorter period of time and not having consumed at a higher level. These issues are complicated by the possible role of annuities in providing insurance against the former risk and bequests as an outcome of the latter risk.

While people should use a planning horizon longer than their life expectancy, their planning horizon should be based on their life expectancy. An important issue is the effect on financial planning of user errors concerning life expectancy. These errors can occur either because the software does not accurately represent the individual's life expectancy when it provides that input or the individual does not have an accurate expectation of his or her own life expectancy when the user provides that information as an input.

Assistance in Choosing Inputs.

1. Relationship between length of planning period and life expectancy. Does the program indicate that the planning period should be longer than life expectancy?

2. Assistance provided in setting length of planning period. Does the program provide assistance in choosing the length of the planning period?

3. Heterogeneity in life expectancy and length of planning period. Does the program allow for heterogeneity in the length of the planning period across different people? 
4. Risk of living to an older age. Does the program provide results for at least two different planning horizons or life expectancies, either through Monte Carlo simulations or through alternative scenarios? Do deterministic programs facilitate or automatically provide different scenarios as to length of planning period?

5. Surviving spouse issues. Does the program take into account the surviving spouse in determining the planning horizon?

Rejection of False Inputs.

6. Rejection of inaccurate inputs. Does the program reject or question life expectancy or planning periods that appear to be too low? At age 60, the average number of years of life remaining is 22, with the figure being 21 for men and 24 for women (U.S. National Center for Health Statistics 2008).

7. Granularity. Does the program recognize that life expectancy varies across users, men and women, for example, and have different rejection or feedback levels for different users.

The Target Replacement Rate or Target Retirement Income. The target replacement rate or target retirement income are determinants of the amount of retirement resources a person needs to support consumption in retirement.

Assistance in Choosing Inputs,

1. Assistance provided. Does the program provide assistance in setting the target?

2. Recognition of differences across family types in targets. Does the program recognize that target replacement rates or target retirement income levels are higher for childless couples or individuals than for persons raising children?

3. Does the program set unreasonably high targets? Some programs set the target replacement rate. If the program sets the target replacement rate, does it recognize differences 
across family types, such as that childless couples might have a higher target than couples with children?

\section{Relationship between income target or replacement rate target and retirement age.}

Does the program recognize that a higher target can be achieved if the worker defers retirement? Rejection of False Inputs.

5. Rejection of inaccurate inputs. Does the program reject or question targets that appear to be too low? While target replacement rates vary across users, replacement rates below 60 percent should be questioned for married couples without children.

6. Granularity. Does the program recognize that target replacement rates vary across users and have different rejection levels for different users? Ideally, programs could determine whether a family has children and permit the setting of different targets for those families than for childless families.

\section{Advice Based on the Projection of Retirement Income.}

7. Advice provided if savings are insufficient. Does the program suggest a lower target if the user has saved insufficiently? Does the program automatically provide results for higher saving rates?

\section{Software Analyzed}

The rating system in this paper is developed for rating Internet-based free retirement planning software. The software is judged as to its usefulness for middle- and lower-income users (upper-income persons are more likely to hire financial planners). The rating system rates against a standard that could be achieved for programs that are simple to use and do not require a lot of time for the user to input the required data. Programs for higher-income users need to have 
greater complexity and sophistication to deal with their more complex finances, and those issues are not considered here.

As an example of the use of the rating system, the following free, internet-based retirement planning programs are rated (their URL websites are also given):

\section{T. Rowe Price Retirement Income Calculator}

http://www3.troweprice.com/ric/ric/public/ric.do

\section{AARP retirement planning calculator}

http://sites.stockpoint.com/aarp_rc/wm/Retirement/Retirement.asp?act=LOGIN

\section{Nationwide Retirability Check}

http://www.nationwide.com/campaign/rcheck_landing.htm?WT.srch=1\&WT.mc_id=bgr00385\& $\underline{002=2074663 \& 004=530874068 \& 005=22245163 \& 006=2965195988 \& 007=\text { Search } \& 008}=$

4. Choose to Save Ballpark Calculator http://www.choosetosave.org/ballpark/

5. EBSA: Taking The Mystery Out Of Retirement Planning

http://askebsa.dol.gov/retirementcalculator/UI/general.aspx

\section{Findings}

The rating system assumes an unsophisticated user who is prone to making the types of mistakes and having the lack of information or misinformation that have been identified in studies concerning behavioral finance. The ratings would generally be higher if a sophisticated user was assumed because there would be less need for assistance with determining inputs or in interpreting outputs. 
Table 1 contains the ratings of the five programs. The ratings contain a degree of subjectivity, but nonetheless reflect the structure established by the rating system. Table 2 provides an interpretation of the rating scale into low, medium, and high scores.

\section{Tables 1 and 2 here}

Social Security. Because of their importance as a source of retirement income for most users, the treatment of Social Security benefits is discussed in greater detail than the other issues rated. The T. Rowe Price program gets low marks for its handling of Social Security since it asks if the user would like to include Social Security benefits in the calculation, which may provide a false impression of the importance of Social Security benefits for most people. The program provides default estimates of Social Security benefits based on a single year of earnings, age, and age at retirement, which is an inaccurate way to estimate benefits. It does not suggest using the Social Security Administration benefits calculator. It indicates that the replacement rate from Social Security is 20 percent, which is considerably lower than the average replacement rate Social Security provides. It accepts false value for Social Security benefits, both too high and too low. It allows users to input Social Security benefits for retirement ages earlier than age 62. A positive feature is that it does suggest retiring later as an option when assets are insufficient.

The AARP program suggests using the SSA benefits calculator, but it allows receipt of Social Security benefits prior to age 62, and it permits the user to input benefits that are too high or too low. It does suggest retiring later as an option when savings are insufficient.

The Nationwide program indicates that Social Security benefits starting in 2040 may be cut by 26 percent and further cuts are likely later; nevertheless, this information was irrelevant to the age of the person input in this testing of the program. The software also suggests that many people do not have confidence in the Social Security system, which is irrelevant for the same 
reason. It sets the retirement age at 65 , with no option for override. It instructs users to assume that Social Security benefits will be available when they retire, which is good advice but which suggests that that is only an assumption.

The Choose to Save program directs the user to the Social Security Administration website, but rather than directing the user to the calculator that provides a personalized benefits estimate, it directs the user to a much less accurate calculator.

The EBSA program in its assistance notes indicates that the earliest age at which Social Security benefits can be received is 62, but the calculator accepts earlier ages without indicating that the input is erroneous. It does reject erroneously high values for Social Security benefits, but it does not provide assistance in determining the level of those benefits. It allows the user to collect Social Security benefits earlier than the user's retirement age, but does not indicate there is an earnings test.

Rate of Return and Financial Risk. T. Rowe Price gets high marks for its handling of rate of return and risk because it uses a Monte Carlo simulation. It is the only one of the five programs considered that does so. The simulation runs 1,000 randomly selected scenarios. AARP allows users to input a portfolio rate of return of 20 percent and the program offers no assistance in setting expected rates of return. On the positive side, it allows different rates of return in different periods.

Turning to other programs, Nationwide requests some detail about pensions but it provides no information as to the rate of return assumption it uses. It does not use Monte Carlo simulation. The Choose to Save calculator appears to assume a sophisticated user. It provides no assistance on choosing rates of return and it accepts rates of return of 20 percent as inputs. The EBSA calculator suggests a conservative rate on all investments of 5 percent as a default. It does 
not permit rates higher than 7 percent or lower than 3 percent. This approach is simple but practical for models that do not use Monte Carlo simulation.

Length of the Planning Period. T. Rowe Price and the EBSA calculator assume that everyone lives to age 95, an approach that does not allow for the considerable heterogeneity in life expectancy. The AARP and the Choose to Save calculators provide no assistance in informing people of their lifespans and accepts unreasonably low values without questioning them. Furthermore, thes equate the length of the planning period to life expectancy, which does not take into account the possibility of living longer. Nationwide does not provide information on the assumed length of the planning period.

Target Replacement Rate or Target Retirement Income. Also important in the retirement planning calculation is how the target retirement income levels are set. Indeed, this is often far from clear. T. Rowe Price and Nationwide do give users a retirement income target but the process is not disclosed. AARP requires the user to set the desired level of retirement consumption and provides a worksheet to help figure that out. Choose to Save has the user enter his or her desired replacement rate, but the program provides no guidance or edit checks. The EBSA calculator provides a detailed worksheet, which could be more tedious than might suit the typical user.

\section{Conclusion and Discusssion}

We develops a rating system for Internet-based free retirement planning software that can accomodate unsophisticated users. The rating system takes into account two of the most important sources of retirement income-Social Security and investments-and the two main determinants of retirement income needs-the length of the planning period and the target 
replacement rate or target retirement income. Of course as a first attempt of developing a rating system for retirement planning software, it is clear that some subjectivity is inherent in both the rating system construction, and in its application. Nonetheless, by establishing categories to be rated and by specifying specific issues within those categories, it is a step in the direction of developing rating systems to encourage the development of improved retirement planning programs and to assist users in choosing programs.

The small sample of programs rated suggest that programs tend to do a poor job in the way they handle Social Security benefits, which is the most important source of retirement income for most people. Some of the programs appear to have an anti-Social Security bias. The treatment of Social Security benefits would be improved if people were advised that it was important to obtain accurate information about their benefits, and that they can easily due so at the Social Security Administration website. Program checks as to errors on the age at which Social Security benefits can be received and the level of benefits, for users making a guess, would also be helpful.

Acknowledgments. The author received helpful comments from Olivia S. Mitchell and Kent Smetters, and he gratefully acknowledges financial support from the Pension Research Council/Boettner Center for Retirement Research at the Wharton School. 


\section{ENDNOTES}

${ }^{1}$ A different rating system would be appropriate for rating financial planning software used by professional retirement planners. Because of the assumption that the financial planner would be sophisticated, the user would thus need less assistance in determining inputs or in interpreting outputs. 


\section{References}

Benitez-Silva, Hugo, Berna Deniralp, and Zhen Liu (2009). ‘Social Security Literacy and Retirement Well Being.’ Michigan Center for Retirement Research, WP 2009-210. http://www.mrrc.isr.umich.edu/publications/papers/pdf/wp210.pdf

Bodie, Zvi (2003). 'An Analysis of Investment Advice to Retirement Plan Participants.’ In Olivia S. Mitchell and Kent Smetters, The Pension Challenge: Risk Transfers and Retirement Income Security. Oxford, UK: Oxford University Press, pp. 19-32.

Bucks, Brian K., Arthur B. Kennickell, Traci L. Mack, and Kevin B. Moore (2009). 'Changes in U.S. Family Finances from 2004 to 2007: Evidence from the Survey of Consumer Finances.’ Federal Reserve Board Working Paper . http://www.federalreserve.gov/pubs/bulletin/2009/pdf/scf09.pdf

Carnahan, Ira (2005). 'The Best of the Web Retirement Planning Tools.' Forbes.com, June 6. http://www.forbes.com/forbes/2005/0606/092sidebar.html

Dichev, Ilia (2007). 'What Are Stock Investors’ Actual Historical Returns?’ American Economic Review 97(1): 386-401.

Dowd, Bryan, Adam Atherly, and Robert Town (2008). 'Planning for Retirement? Web Calculators Weak on Health Care Costs.’ AARP Public Policy Institute Working Paper .

Gustman, Alan L. and Thomas L. Steinmeier (2003). 'What People Don't Know About Their Pensions and Social Security: An Analysis Using Linked Data from the Health and Retirement Study.’ In William G. Gale, John B. Shoven and Mark J. Warshawsky, Private Pensions and Public Policies. Washington, D.C.: Brookings Institution, pp. 57119. 
Hill, Catherine and Virginia P. Reno (2005). 'The Financial Case for Late Retirement.' In, Teresa Ghilarducci, Van Dooorn Ooms, John L. Palmer, and Catherine Hill, In Search of Retirement Security. New York: The Century Foundation Press.

Hurd, Michael D. and Kathleen McGarry (1995). 'Evaluation of the Subjective Probabilities of Survival in the Health and Retirement Survey.' Journal of Human Resources 30 (Supplement) S268- S292.

Hurd, Michael D. and Susann Rohwedder (2003). 'The Retirement-Consumption Puzzle: Anticipated and Actual Declines in Spending at Retirement.' NBER Working Paper 9586.

Investment Company Institute (2006). 'Understanding Investor Preferences for Mutual Fund Information.’ http://www.ici.org/pdf/rpt_06_inv_prefs_full.pdf

Kotlikoff, Laurence L. (2006). 'Is Conventional Financial Planning Good for Your Financial Health?' http://people.bu.edu/kotlikoff/Is\%20Conventional\%20Financial\%20Planning\%20Good\% 20for\%20Your\%20Financial\%20Health.pdf

Landis, David (2007). 'Rating the Online Retirement Planners.' Kiplinger, August. http://www.winknightsmoney.org/magazine/archives/2007/08/financialplans.html?kipad $\underline{\mathrm{id}=2}$

Lusardi, Annamaria and Olivia S. Mitchell (2008). 'How Much Do People Know About Economics and Finance? Financial Literacy and the Importance of Financial Education.' Michigan Retirement Research Center Policy Brief \#5, Michigan Retirement Research Center, Ann Arbor, Michigan. 
Madden, William (2008). Will I Have Enough to Retire? Russell Research Report. Russell Investments, May 23.

McClure, Dave (2005). 'Software Review: Financial Planning Segments.' WebCPA. http://www.webcpa.com/article.cfm?articleid=10145\&page=1

Metlife (2008). Metlife Retirement Income IQ Study. http://www.metlife.com/assets/cao/mmi/publications/studies/MMI-Studies-RetirementIQ.pdf

Mitchell, Olivia S. (1988). ‘Worker Knowledge of Pension Provisions.' Journal of LaborEconomics. 6(1): 21-39.

Munnell, Alicia H., Mauricio Soto and Jean-Pierre Aubry (2009). 'Do People Plan to Tap their Home Equity in Retirement?' Issue in Brief, Center for Retirement Research at Boston College.

Murray, Christopher J. L., Sandeep C. Kulkarni, Catherine Michaud, Niels Tomijima, Maria T. Bulzacchelli, Terrel J. Iandiorio, and Majid Ezzati (2006). ‘Eight Americas Investigating Mortality Disparities across Races, Counties, and Race-Counties in the United States.' PLoS Medicine vol. 3, Issue 9.

http://medicine.plosjournals.org/perlserv?request=getdocument\&doi=10.1371/journal.pmed.0030260

Purcell, Patrick (2008). 'Income and Wealth of Older Americans.' Congressional Research Service.

Rohwedder, Susann and Kristin J. Kleinjans (2004). 'Dynamics of Individual Information about Social Security.' Paper presented at the Annual Meeting of the Population Association of America, Boston. 
Saving, Thomas R. (2009). 'Don’t Judge 401(k)s in a Crisis.’ New York Times, March 25. http://roomfordebate.blogs.nytimes.com/2009/03/25/so-much-for-the-401k-now-what/ Scholz, John Karl and Ananth Seshadri (2009). 'What Replacement Rates Should Households Use?’ University of Michigan Retirement Research Center WP 2009-214, September. http://www.mrrc.isr.umich.edu/publications/papers/pdf/wp214.pdf

Social Security Administration (2010). ‘Social Security Online: Questions.’ http://ssacusthelp.ssa.gov/cgi-bin/ssa.cfg/php/enduser/std_adp.php?p_faqid=310

Society of Actuaries (2004). '2003 Risks and Process of Retirement Survey.' Prepared by Matthew Greenwald and Associates, Inc. http://www.soa.org/files/pdf/Retirement_Risk_2-12_FINAL_V2.pdf

Sondergeld, Eric T., Robert S. Chamerda, Matthew Drinkwatter, and Daniel G. Landsberg (2003). Retirement Planning Software. LIMRA International, Inc. and the Society of Actuaries, in collaboration with the International Foundation for Retirement Education. Sondergeld, Eric T. and Matthew Greenwald (2005). 'Public Misperceptions about Retirement Security,' LIMRA, International, the Society of Actuaries, and Mathew Greenwald \& Associates Report. Hartford, Ct., Schaumburg, Il and Washington, DC.

Turner, John A. and Hazel A. Witte (2009). 'Retirement Planning Software and Post-Retirement Risks.' Report for the Society of Actuaries and the Actuarial Foundation. http://www.soa.org/research/pension/retire-planning-software-post-retire-risk.aspx U.S. National Center for Health Statistics (2008). 'National Vital Statistics Reports.' http://www.census.gov/compendia/statab/2010/tables/10s0103.pdf Warshawsky, Mark and John Ameriks (2000). 'How Prepared Are Americans for Retirement?' In Olivia S. Mitchell, P. Brett Hammond, and Anna M. Rappaport, Forecasting 
Retirement Needs and Retirement Wealth. Philadelphia, PA: University of Pennsylvania Press, pp. 33-67. 
Table 1. Rating of Retirement Planning Software

\begin{tabular}{|c|c|c|c|c|c|}
\hline Programs & $\begin{array}{l}\text { Social } \\
\text { Security } \\
\text { (30 points } \\
\text { maximum) }\end{array}$ & $\begin{array}{l}\text { Rates of } \\
\text { return and } \\
\text { risk } \\
\text { ( } 20 \text { points } \\
\text { maximum) }\end{array}$ & $\begin{array}{l}\text { Planning } \\
\text { period or life } \\
\text { expectancy } \\
\text { ( } 25 \text { points } \\
\text { maximum) }\end{array}$ & 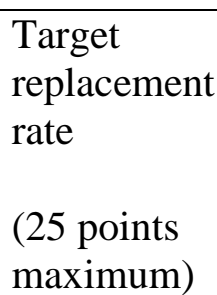 & $\begin{array}{l}\text { (100 points } \\
\text { maximum) }\end{array}$ \\
\hline $\begin{array}{l}\text { Choose to } \\
\text { Save }\end{array}$ & 20 & 10 & 10 & 20 & 60 \\
\hline AARP & 20 & 15 & 10 & 22 & 67 \\
\hline EBSA & 20 & 18 & 18 & 18 & 74 \\
\hline $\begin{array}{l}\text { T. Rowe } \\
\text { Price }\end{array}$ & 15 & 18 & 15 & 15 & 63 \\
\hline Nationwide & 15 & 10 & 10 & 15 & 50 \\
\hline
\end{tabular}

Source: Author's compilation

Table 2. Rating Scale for Categories with Different Maximum Points

\begin{tabular}{|l|l|l|l|l|}
\hline & $\begin{array}{l}\text { Maximum 20 } \\
\text { category }\end{array}$ & $\begin{array}{l}\text { Maximum 25 } \\
\text { category }\end{array}$ & $\begin{array}{l}\text { Maximum 30 } \\
\text { category }\end{array}$ & $\begin{array}{l}\text { Maximum 100 } \\
\text { Total }\end{array}$ \\
\hline Low & 10 & 10 & 15 & 45 \\
\hline Medium & 15 & 15 & 20 & 65 \\
\hline High & 18 & 20 & 25 & 83 \\
\hline
\end{tabular}

Source: Author's compilation 